\title{
Letter to the Editor: The Distribution of Brush Border Peptidases along the Small Intestine of the Adult Human
}

\author{
ERWIN E. STERCHI \\ Department of Gastroenterology, University Children's Hospital, Freiburgstrasse 15, 3010 Bern, Switzerland
}

Recently, Andria et al. (1) reported their findings of a study on the peptidase activities of the human small intestine in normal subjects and coeliac patients. Having demonstrated the presence of aminopeptidase M (EC 3.4.11.2), aminopeptidase A (EC 3.4.11.7), and dipeptidylpeptidase IV (EC 3.4.14.-) in the brush border membrane of normal human small intestine (5-7), we had studied the possible involvement of these enzymes in the aetiology of coeliac disease in our laboratory. Our results so far, obtained with mucosal biopsies taken at the ligament of Treitz, essentially coroborate the results of Andria et al. (1).

We have now also been able to study the distribution of these enzymes along the entire human small intestine. The following
Sterchi and Woodley (6). Results are expressed as $\mu$ moles substrate hydrolysed per min per g protein at $37^{\circ} \mathrm{C}$,

As shown in Figure 1, the specific activity of the membranebound aminopeptidase $\mathrm{A}$ increases approximately 6-fold from 1.9 units/g protein near the pylorus to 11.0 units/g protein at the ileocaecal junction. Similarly, dipeptidylpeptidase IV activity in the particulate fraction increases approximately 3 -fold along the length of the gut from 2.07 to 5.95 units/g protein. In contrast, the specific activity of the particulate aminopeptidase $M$ varies from 21.5 to 31.2 units/g protein with no apparent increase in the distal gut (Fig. 2). Sucrase activity is low in the first proximal section of gut, reaches maximum values in the mid-jejunum, and declines

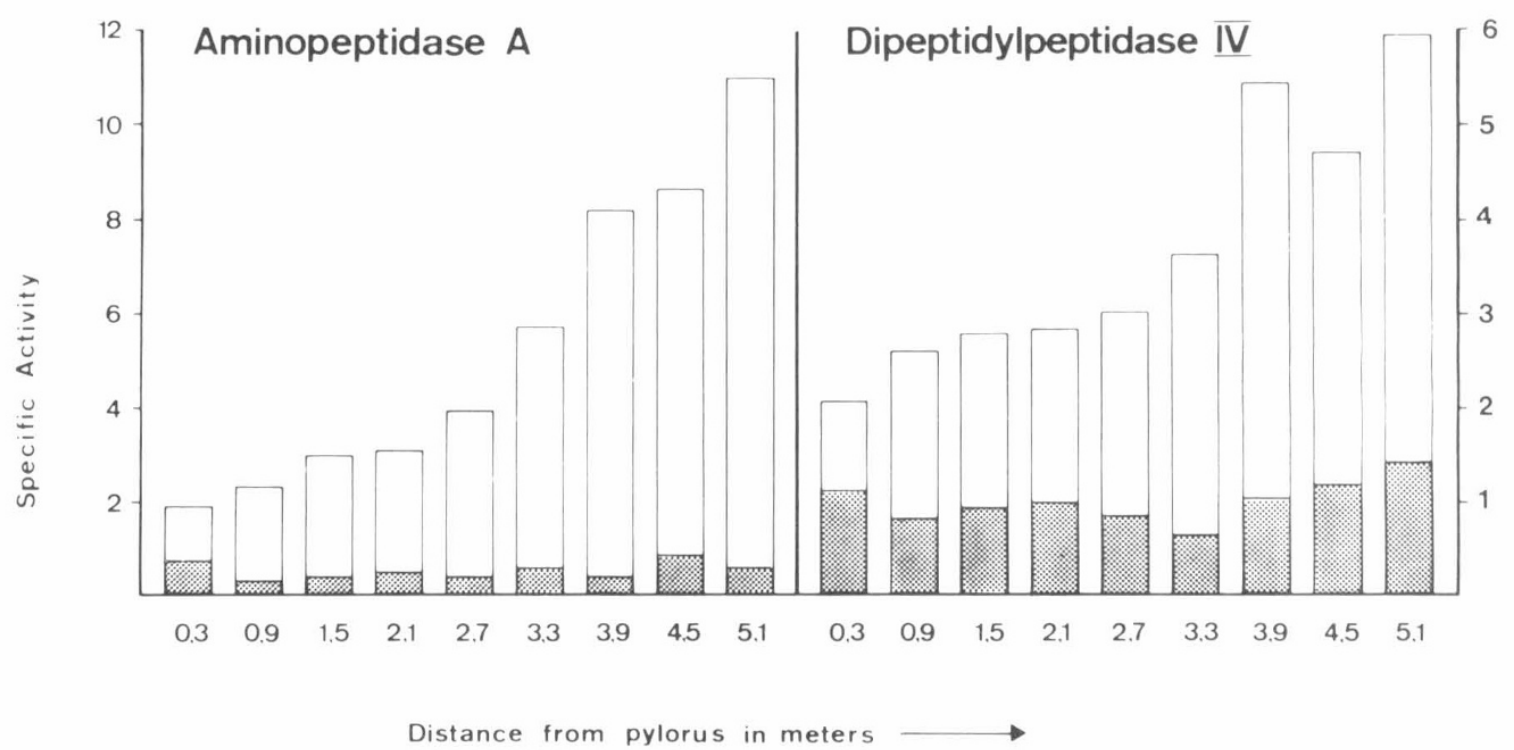

Fig. 1. Distribution of aminopeptidase A and dipeptidylpeptidase IV along the human small intestine. Specific activity is expressed as $\mu$ moles substrate hydrolysed per min per $g$ of protein. $\square$, specific activity in particulate fraction; 圈, specific activity in soluble fraction.

results were obtained with the intestine from a 29 -year-old male kidney donor. Immediately after removal, the intestine was cut into 17 sections, $30 \mathrm{~cm}$ long, which were then rinsed through with $0.15 \mathrm{M} \mathrm{NaCl}$ at $4^{\circ} \mathrm{C}$. Each piece of gut was drained, wrapped in aluminium foil, and frozen with solid $\mathrm{CO}_{2}$. The mucosa of a $2 \mathrm{~cm}$ section, cut off the distal end of each piece, was scraped away and homogenised at a final concentration of $2.5 \% \mathrm{w} / \mathrm{v}$ in $2 \mathrm{mM}$ Tris/ $50 \mathrm{mM}$ mannitol buffer, $\mathrm{pH}$ 7.4. Peptidase activity was measured in supernatant and resuspended pellet after centrifugation of the homogenate at $100,000 \times g$ for $1 \mathrm{hr}$. Protein was measured by the method of Lowry et al. (4), sucrase activity by the method of Dahlqvist (3), and peptidase activities by the method described by slightly towards the distal ileum (Fig. 2). The soluble activity of all enzymes is considerably lower than that in the particulate fraction and does not show any marked proximal to distal variation.

These results are in agreement with those obtained with rabbit intestine (2), and they emphasize the role of the ileal mucosa in peptide digestion. Furthermore, it is clear that peptidase activities measured in peroral biopsies of duodenal mucosa, taken near the ligament of Treitz, are not representative of enzyme levels in the distal gut. Thus, the validity of results from work with such biopsies on the involvement of peptidases in intestinal disease, especially coeliac disease, must be questioned. 


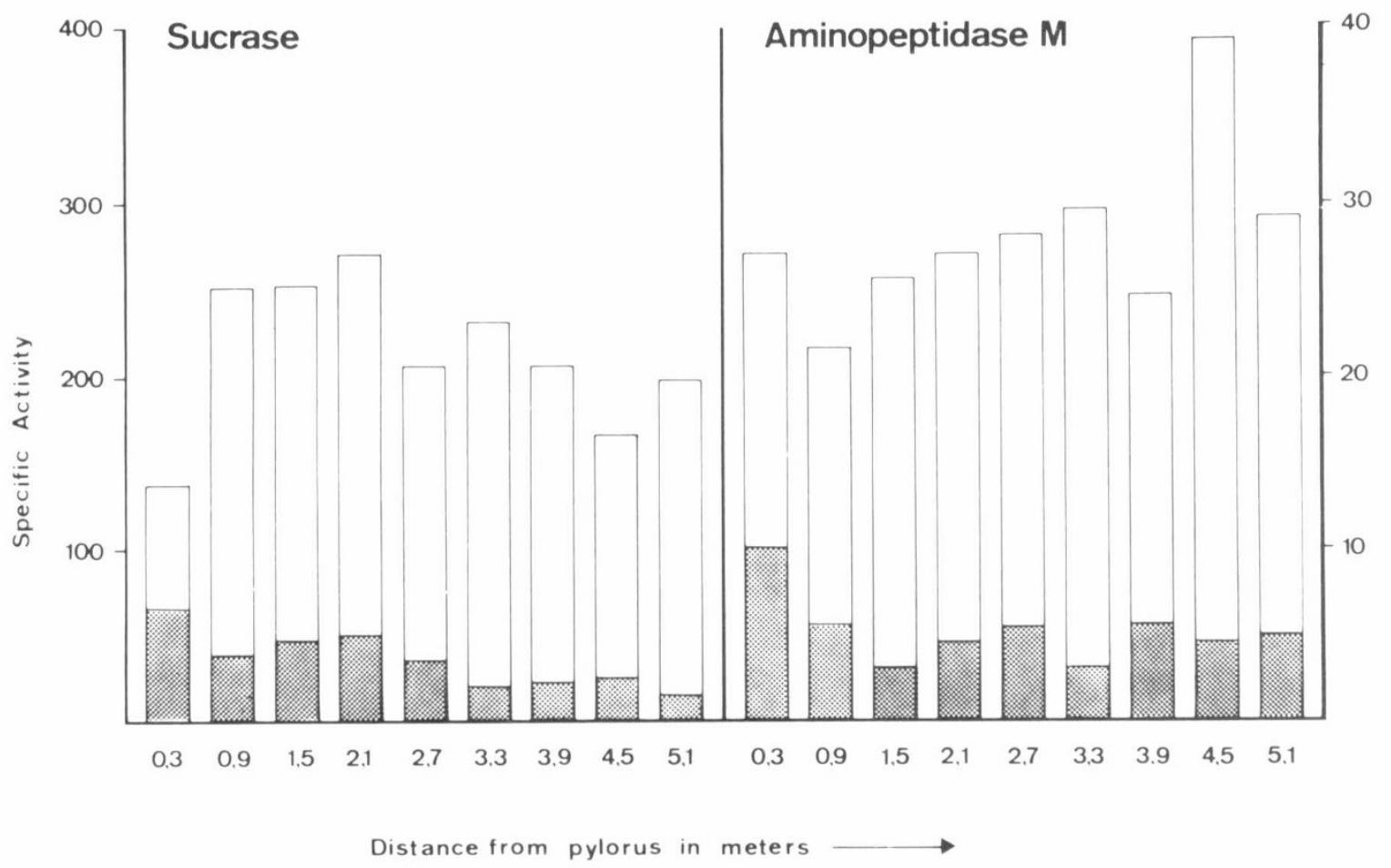

Fig. 2. Distribution of aminopeptidase $M$ and sucrase along the human small intestine. Details as in Figure 1.

REFERENCES AND NOTES

1. Andria, G., Cucchiara, S., DeVizia, B., DeRitis, G., Mazzacca, G., and Auricchio, S.: Brush border and cytosol peptidase activities of human small intestine in normal subjects and coeliac patients. Pediatr. Res., 14: 812 (1980).

2. Auricchio, S., Greco, L., DeVizia, B., and Buonocore, V.: Dipeptidylaminopeptidase and carboxypeptidase activities of the brush border of rabbit small intestine. Gastroenterology, 75: 1073 (1978).

3. Dahlqvist, A.: Assay of intestinal disaccharidases. Anal Biochem., 22: 99 (1968).

4. Lowry, O. H., Rosebrough, N. J., Farr, A. L., and Randall, R. J.: Protein measurements with the Folin phenol reagent. J. Biol. Chem., 913: 265 (1951).

5. Sterchi, E. E., and Woodley, J. F.: Peptidases of the human intestinal brush border membrane. In: B. McNicholl, C. F. McCarthy, P. F. Fottrell: Perspectives in Coeliac Disease. pp. 437-449 (MTP Press Limited, Lancaster, England. 1978).

6. Sterchi, E. E. and Woodley, J. F.: Peptide hydrolases of the human small intestinal mucosa: distribution of activities between brush border membranes and cytosol. Clin. Chim. Acta, 102: 49 (1980).

7. Sterchi, E. E., and Woodley, J. F.: Peptide hydrolases of the human small intestinal mucosa: Identification of six distinct enzymes in the brush border membrane. Clin. Chim. Acta, 102: 57 (1980).

8. The cooperation of Dr. A. Krneta is gratefully acknowledged.

9. This research was supported by grant $3.957-0.78$ from the Swiss National Science Foundation.

\title{
Letter to the Editor: Distribution of the Brush Border Peptidase Activities along the Small Intestine
}

\author{
SALVATORE AURICCHIO
}

Clinica Pediatrica, II Facolta de Medicina e Chirurgia, Via Sergio Pansini 5, 80131 Napoli, Italy

We have studied (1) the distribution of the peptidase activities of the brush border along the small intestine of eight human fetuses aged between 16 and $22 \mathrm{wk}$, and we have found results which are similar to those reported by Sterchi in his letter and by us in previous studies in rabbit (2): the peptidase activities are higher in the distal third than in the proximal one.

Nevertheless, we think that the presence of normal levels of peptidase activities in the proximal part of the small intestine in coeliac patients in histologic remission suggests that these activities are normal along the small intestine and that no primary deficiency of these peptidase activities exists in the coeliac disease.

\section{REFERENCES AND NOTES}

1. Auricchio, S., Stellato, A., and De Vizia, B.: Development of brush border peptidases in human and rat small intestine during fetal and neonatal life. Submitted to Pediatr. Res.

2. Auricchio, S., Greco, L., DeVizia, B., and Buonocore, V.: Dipeptidylaminopeptidase and carboxypeptidase activities of the brush border of rabbit small intestine. Gastroenterology, 75: 1073 (1978). 